Varga, Zsuzsanna. "Selected English-Language Bibliography of Interest for Hungarian Cultural Studies: 2016-

2017." Hungarian Cultural Studies. e-Journal of the American Hungarian Educators Association, Volume 10 (2017)

DOI: $10.5195 /$ ahea.2017.312

\title{
Selected English-Language Bibliography of Interest for Hungarian Cultural Studies: 2016-2017
}

\section{Zsuzsanna Varga}

\begin{abstract}
As the above title indicates, because of the publication schedule of Hungarian Cultural Studies this bibliography straddles 2016-2017, covering the period since the publication in Fall of 2016 of last year's bibliography in this journal. Each year's bibliography may also be supplemented by earlier items, which were retrieved only recently. Although this bibliography series can only concentrate on English-language items, occasional items of particular interest in other languages may be included. For a more extensive bibliography of Hungarian Studies from about 2000 to 2010, for which this is a continuing update, see Louise O. Vasvári, Steven Tötösy de Zepetnek, and Carlo Salzani. "Bibliography for Work in Hungarian Studies as Comparative Central European Studies.” CLCWeb: Comparative Literature and Culture (Library) (2011): http://docs.lib.purdue.edu/clcweblibrary/hungarianstudiesbibliography/
\end{abstract}

Biography: Zsuzsanna Varga studied English, Hungarian and Portuguese language and literature at Eötvös Loránd University, Budapest. She took her PhD in 19th century English literature at Edinburgh University. She has taught and researched at different British universities, including the University of Essex, UCL and De Montfort University. She has taught Hungarian Studies at Glasgow University since 2008, and she is also in charge of the Hungarian library collection at the University of Oxford. Her research interests include nineteenth-century women's writing, travel writing and translation history. Zsuzsanna.Varga@glasgow.ac.uk

Abádi-Nagy, Zoltán. 2016. “Rózsa Ignácz's 'Torockói gyász' ['Torocko Mourning']: Identity Beyond the Borders of Time and Space." Hungarian Cultural Studies 9: 28-42. https://ahea.pitt.edu/ojs/index.php/ahea/article/view/249

Arany, Krisztina. 2017. "Florentine Families in Hungary in the First Half of the Fifteenth Century." Hungarian Historical Review 6.1: 5-39.

Balogh, Eszter Edit. 2017. "Women's Testimonies of their Changing Roles during the First World War in English and Hungarian Culture." Intertextuality, Intersubjectivity, and Narrative Identity. Ed. Péter Gaál-Szabó. Newcastle: Cambridge Scholars Publishing: 119-133.

Bajomi-Lázár, Péter. 2014. Party Colonisation of the Media in Central and Eastern Europe. Budapest: CEU UP.

Barcsa, Krisztina and Máté-Tóth, András. 2016. "The Hungarian Religious Leaders Statements from the Beginning of the Migration.” Occasional Papers on Religion in Eastern Europe 36.3: 1-14. 
Varga, Zsuzsanna. "Selected English-Language Bibliography of Interest for Hungarian Cultural Studies: 2016-

2017." Hungarian Cultural Studies. e-Journal of the American Hungarian Educators Association, Volume 10 (2017) DOI: $10.5195 /$ ahea.2017.312

Bassett, Richard. 2015. For God and Kaiser: The Imperial Austrian Army from 1619 to 1918. New Haven: Yale University Press.

Bengi, László et al. 2017. Hungarian Perspectives on the Western Canon: Post-Comparative Readings. Newcastle: Cambridge Scholars Publishing. [Forthcoming Review in this journal, 2018, by András Kiséry].

Berger Stefan and Alexei Miller, eds. 2015. Nationalizing Empires. Budapest: Central European UP.

Bodó, Béla. 2016. "Caught between Independence and Irredentism: the 'Jewish Question' in the Foreign Policy of the Kállay Government, 1942-1944.” Hungarian Studies Review 43. 1-2: 83-126.

Borgos, Anna and Dorottya Rédai. 2016. "Labrisz Lesbian Association and the Lesbian Herstory Archives Hungary." Aspasia 10.1: 224-226.

Botz-Bornstein, Thorsten. 2017. Organic Cinema: Film, Architecture, and the Work of Béla Tarr. New York-Oxford: Berghahn.

Bozóki, András and Miklós Sükösd. 2017. "Third- Way Utopianism: Anarcho-Democratic and Liberal Socialist Ideas in Central Europe.” Utopian Horizons: Ideology, Politics, Literature. Ed. Zsolt Czigányik. Budapest: CEU UP: 77-101.

Bridge, F. R. 2016. "Sir Edward Grey and Austria-Hungary." International History Review 38.2: $264-274$.

Burke, Linda. 2016. "A Sister in the World: Saint Elizabeth of Hungary in the Golden Legend." Hungarian Historical Review 5.3: 509-535.

Csonka-Takács Eszter. 2016. "Intangible Cultural Heritage Communities in the Network of the Skanzen Hungarian Open Air Museum.” Acta Ethnographica Hungarica 61.2: 431-439.

Czeglédi, Sándor. 2017. "Miller vs. "Arminius": Contested Influences on Bram Stoker's Dracula." Displacing the Anxieties of our World: Spaces of the Imagination. Ed. Ildikó Limpár. Newcastle: Cambridge Scholars Publishing: 102-119.

Czigányik, Zsolt. 2017. "Negative Utopia in Central Europe: Kazohinia and the Dystopian Political Climate of the 1930s." Utopian Horizons: Ideology, Politics, Literature. Ed. Zsolt Czigányik. Budapest: CEU UP: 161-179. . 2016. "The Hungarian Translations of Thomas More's Utopia." Utopian Studies 27.2: 323-332.

Dale, Gareth. 2016. Karl Polanyi: A Life on the Left. New York: Columbia University Press. [Forthcoming Review in this journal, 2018, by Andrew Gollner].

Danyi, Gábor. 2016. "Fidelity and Testimony: Publishing, Censorship and Commentary in József Lengyel's Confrontation." Ulbandus 17: 17-41. . 2016. "Phantom Voices from the Past: Memory of the 1956 Revolution and Hungarian Audiences of Radio Free Europe.” Hungarian Historical Review 5.4: 790-813.

Deak, John, 2015. Forging a Multinational State: State Making in Imperial Austria from the Enlightenment to the First World War. Stanford, CA: Stanford University Press.

Dobos, István. 2016. "Humanities in Hungary Lose a Benchmark of a Scholar: In Memoriam Mihály Szegedy-Maszák.” Hungarian Studies 30.2: 263-266.

Draskóczy, István. 2017. "Austrian Salt in Pozsony in the Mid-Fifteenth Century." Hungarian Historical Review 6.1: 63-81.

Dreisziger, Nándor. 2016. "The Saint Elizabeth of Hungary Roman Catholic Parish of Toronto: Nine Decades of Evolution." Hungarian Studies Review 43.1-2: 59-82. 
Varga, Zsuzsanna. "Selected English-Language Bibliography of Interest for Hungarian Cultural Studies: 2016-

2017." Hungarian Cultural Studies. e-Journal of the American Hungarian Educators Association, Volume 10 (2017) DOI: $10.5195 /$ ahea.2017.312

Fábián, Katalin and Elzbieta Korolczuk. 2017. Rebellious Parents: Parental Movements in Central-Eastern Europe and Russia. Bloomington, IN: Indiana UP. [Forthcoming Review in this journal, 2018, by Erika Kispéter].

Fara, Andrea. 2017. "Production of and Trade in Food Between the Kingdom of Hungary and Europe in the Late Middle Ages and Early Modern Era (Thirteenth to Sixteenth Centuries): The Roles of Markets in Crises and Famines." Hungarian Historical Review 6.1:138-179.

Farkas, Ákos. 2017. "What They Were Going to Do about It: Huxley's Peace Pamphlet in PreWar Hungary." Utopian Horizons: Ideology, Politics, Literature. Ed. Zsolt Czigányik. Budapest: CEU UP: 181-199.

Feichtinger, Johannes and Gary B Cohen. 2016. Understanding Multiculturalism: The Habsburg Central European Experience. New York-Oxford: Berghahn. [Forthcoming Review in this journal, 2018, by Christopher VanDemark].

Félix, Anikó. 2017. "Towards an Alternative Emancipation? The New Way(s) of Women's Mobilisation in the Hungarian Radical Right Subculture." Gender and Far Right Politics in Europe. Eds. Michaela Köttig, Renate Bitzan and Andrea Pető. Cham, Switzerland: Palgrave Macmillan: 95-109.

Ferdinand, Siarl. 2016. "Situation of the Csángó Dialect of Moldavia in Romania." Hungarian Cultural Studies 9: 72-89. http://ahea.pitt.edu/ojs/index.php/ahea/article/view/231

Forgács, Éva. 2016. Hungarian Art: Confrontation and Revival in the Modern Movement. Los Angeles: Doppelhouse Press. [See review by Oliver Botar in this issue]

Frey, David Stephen. 2016. "A Smashing Success? The Paradox of Hungarian Cultural Imperialism in Nazi New Order Europe, 1939-42." Journal of Contemporary History 51.3: 577-605.

Fu, Q. 2016. "East-European Marxist Literary Theory: A Conversation." Foreign Literature Studies/Wai Guo Wen Xue Yan Jiu, 38.5: 1-8.

Gatejel, Luminita. 2016. "Overcoming the Iron Gates: Austrian Transport and River Regulation on the Lower Danube, 1830s-1840s." Central European History 49.2: 162-180.

Gergely, Gábor. 2017. "You Cannot Be Sirius! Hungarian Nationalist Science Fiction." Studies in Eastern European Cinema 8.2: 117-130.

http://www.tandfonline.com/doi/abs/10.1080/2040350X.2017.1284979? journalCode=reec20

Gergely, Gábor. 2016. "Women Directors in Hungarian Cinema 1931-44." Studies in Eastern European Cinema 7.3: 258-273. http://www.tandfonline.com/doi/abs/10.1080/2040350X.2016.1216775

Geszler, Nikolett. 2016. "Behaviour-Based Work-Family Conflict among Hungarian Manager Fathers." Intersections 2.3: 118-136.

Gille, Zsuzsa. 2016. Paprika, Foie Gras, and Red Mud: The Politics of Materiality in the European Union. Bloomington: Indiana UP. [Forthcoming Review in this journal, 2018, by Katalin Fábián].

Gingrich, Andre. 2016. "Science, Race, and Empire: Ethnography in Vienna before 1918." East Central Europe 43.1-2: 41-63.

Gioielli, Emily R. 2017. "'Home Is Home No Longer:' Political Struggle in the Domestic Sphere in Postarmistice Hungary, 1919-1922.” Aspasia 11.1: 54-70. 
Varga, Zsuzsanna. "Selected English-Language Bibliography of Interest for Hungarian Cultural Studies: 2016-

2017." Hungarian Cultural Studies. e-Journal of the American Hungarian Educators Association, Volume 10 (2017) DOI: $10.5195 /$ ahea.2017.312

Glajar, Valentina, Alison Lewis and Corina L. Petrescu, eds. 2016. Secret Police Files from the Eastern Bloc - Between Surveillance and Life Writing. Suffolk, UK: Boydell and Brewer. [Reviewed in this issue by Veronika Schandl]

Glant, Tibor. 2016. "US-Hungarian Relations Ten Years After 1956." Hungarian Cultural Studies 9: 184-196. https://doi.org/10.5195/ahea.2016.262

Glanz, Susan. 2016. 'Nicholas L. Deak, the Hungarian 'James Bond' of the World of Money." Hungarian Studies Review 43.1-2: 39-58. http://epa.oszk.hu/00000/00010/00051/pdf/EPA00010_hsr_2016_039-058.pdf

Gluck, Mary. 2016. The Invisible Jewish Budapest: Metropolitan Culture at the Fin de Siècle. Madison, Wisconsin: U. of Wisconsin P. [Reviewed in this issue by Maya Lo Bello]. Gömöri, George and Mari Gömöri, eds. 2016. The Alien in the Chapel: Ferenc Békássy, Rupert Brooke's Unknown Rival. Poems and Letters. Newbold on Stour: Skyscraper Publications.

Görözdi, Judit. 2016. “'Who is Who-the Face as a Mask:”" Péter Esterházy’s Autobiographical Pact with his Readers (Celestial Harmonies, Revised Edition)." Hungarian Studies 30.1: 17-55.

Györkös, Attila. 2016. "The Saint and His Finger: Dominican Legends and Exempla from Thirteenth-Century Hungary." Hungarian Historical Review 5.3: 536-556.

Hajtó, Vera. 2016. Milk Sauce and Paprika: Hungarian Children Living with Belgian Families during the Interwar Period. Leuwen: Leuwen UP.

Harms, Victoria. 2017. "A Tale of Two Revolutions: Hungary's 1956 and the Un-Doing of 1989." East European Politics and Societies 31.3: 479-499.

Ives, Bob et al. 2016. "Applying Intergroup Contact Theory to Social Distance Data from Ethnic Hungarians and Romanians in Romania." Journal of Contemporary European Studies 24.3: 341-355.

Jaritz, Gerhard and Katalin Szende. 2016. Medieval East Central Europe in a Comparative Perspective from Frontier Zones to Lands in Focus. London: Routledge. [Review Forthcoming in this journal, 2018, by Otto Gecser]

Jobbitt, Steven. 2016. "Hungarian Martyrs, Refugees, and the Politics of Anticommunism in Salazar's Portugal, 1956-1957." Hungarian Cultural Studies 9: 137-164. https://doi.org/10.5195/ahea.2016.263

Juhász, Katalin. 2016. "Body - Identity - Society: Concepts of the Socially Accepted Body in the Twentieth Century in Hungarian Rural Areas." Acta Ethnographica Hungarica 61.2: 283-312.

Kasznár, Attila. 2016. "The Chinese Culture and Hungary." Occasional Papers on Religion in Eastern Europe 36.3: 15-24.

Kékesi, Zoltán. 2016. Agents of Liberation: Holocaust Memory in Contemporary Art and Documentary Film. Saint Helena: Helena History Press. [Forthcoming Review in this journal, 2018, by Cathy Portuges ].

Kemecsi, Lajos. 2016. "Plans and Concepts: Opportunities and Challenges Associated with the New Building of the Museum of Ethnography.” Acta Ethnographica Hungarica 61.2: 383-394.

Kind-Kovacs, Friederike. 2014. Written Here, Published There: How Underground Literature Crossed the Iron Curtain. Budapest: CEU UP. 
Varga, Zsuzsanna. "Selected English-Language Bibliography of Interest for Hungarian Cultural Studies: 2016-

2017." Hungarian Cultural Studies. e-Journal of the American Hungarian Educators Association, Volume 10 (2017) DOI: $10.5195 /$ ahea.2017.312

Kiséry, András, Zsolt Komáromy and Zsuzsanna Varga, eds. 2016. Worlds of Hungarian Writing - National Literature as Intercultural Exchange. Lanham, MD: Rowman and Littlefield. [Reviewed in this issue by Peter Sherwood].

Kiss, Tamás and István Gergő Székely. 2016. "Shifting Linkages in Ethnic Mobilization: The Case of RMDSZ and the Hungarians in Transylvania." Nationalities Papers 44.4: 591-610.

Klimó, Árpád von. 2016. "1956 and the Collapse of Stalinist Politics of History: Forgetting and Remembering the 1942 Újvidék/Novi Sad Massacre and the 1944/45 Partisan Retaliations in Hungary and Yugoslavia (1950s-1960s)." Hungarian Historical Review 5.4: 739-766.

Konrád, Eszter. 2016. "Blessed Lancelao of Hungary: A Franciscan Observant in FifteenthCentury Italy." Hungarian Historical Review 5.3: 645-674.

Koudela, Pál and Jin-il Yoo. 2016. "Hungarian War Hero, Factory Founder and Refugee in the United States -Tivadar Rombauer Pál.” Hungarian Studies 30.1: 3-16.

Kránicz, Bence. 2016. "In-Between Worlds, In-Between Images: Workshop on Intermediality in Contemporary Central and East European Cinema, 30-31 May 2016, Sapientia Hungarian University of Transylvania, Cluj-Napoca, Romania." Studies in Eastern European Cinema 7.3: 293-295.

Kunt, Gergely. 2017. "Wartime Sexual Economy as Seen Through a Hungarian Woman's World War II Diary." Feminist Studies, 43,1: 108-133.

http://ezproxyprd.bodleian.ox.ac.uk:2066/10.15767/feministstudies.43.1.0108 . 2016. "Ágnes Zsolt's Authorship of her Daughter Eva Heyman's Holocaust Diary." Hungarian Studies Review 43.1-2: 83-126. http://epa.oszk.hu/00000/00010/00051/pdf/EPA00010_hsr_2016_127-154.pdf . 2016. "The Collaborative Illustrated Diaries of Two Preadolescent Boys During the 1956 Revolution." Hungarian Cultural Studies 9: 101-121. https://doi.org/10.5195/ahea.2016.252

Kurimay, Anita. 2016. "Interrogating the Historical Revisionism of the Hungarian Right: The Queer Case of Cecile Tormay." East European Politics and Societies and Cultures 30.1: $10-33$.

Kürti, László. 2016. "Documenting Immigrants, Boarding Houses and Ethnographers." Hungarian Cultural Studies 9: 231-238. https://doi.org/10.5195/ahea.2016.237

Kwan, Jonathan. 2013. Liberalism and the Habsburg Monarchy, 1861-1895. Basingstoke: Palgrave Macmillan.

Laczó, Ferenc. 2017. Hungarian Jews in the Age of Genocide - An Intellectual History 19291948. Leiden and Boston: Brill. [Forthcoming Review in this journal, 2018, by Péter Kenézl and Joanna Wawrzyniak. 2017. "Memories of 1989 in Europe between Hope, Dismay, and Neglect." East European Politics and Societies 31.3: 431-438. . No Ed. 2015. (Proceedings of:) Bevésett nevek - Az ELTE Holokauszt - és második világháborús emlékmüvének felavatásához kapcsolódó konferencia. Budapest: ELTE Bölcsészettudományi Kar.

Lafferton, Emese. 2016. "Race, Science and Medicine in Central and Eastern Europe around 1900: An Introduction.” East Central Europe 43.1-2: 1-13. 
Varga, Zsuzsanna. "Selected English-Language Bibliography of Interest for Hungarian Cultural Studies: 2016-

2017." Hungarian Cultural Studies. e-Journal of the American Hungarian Educators Association, Volume 10 (2017) DOI: $10.5195 /$ ahea.2017.312

László, János. 2014. Historical Tales and National identity. An introduction to Narrative Social Psychology. London: Routledge.

Lengyel, Imre et al. 2017. "Spatial Differences of Reindustrialization in a Post-Socialist Economy: The Hungarian Counties." European Planning Studies 25.8: 1416 -1434.

Livezeanu, Irina and Arpad von Klimo, eds. 2017. The Routledge History of East Central Europe. London: Routledge.

Lo Bello, Maya J. 2016. "The Holocaust Journal of Miksa Fenyő.” Hungarian Cultural Studies 9: 60 -71. https://ahea.pitt.edu/ojs/index.php/ahea/article/view/230

Maxwell, Alexander. 2016. "Hungaro-German Dual Nationality: Germans, Slavs, and Magyars during the 1848 Revolution." German Studies Review 39.1: 17-39.

Mazierska, Ewa. 2016. "Representation of Slow Violence in the Films about Collapsed East European State Farms." Hungarian Journal of English and American Studies, 22.2: 327-350.

Monok, István. 2016. "Similarities and Differences in the Book History of Central Europe in the Early Modern Period: Aspects and Examples." Hungarian Studies 30.2: 137-153.

Mordovin, Maxim. 2017. "Bavarian Cloth Seals in Hungary." Hungarian Historical Review 6.1: 82-106.

Muray, L. A. 2017. "Creativity and its Ambiguities." Uniting Regions and Nations through the Looking Glass of Literature. Ed. Karoline Szatek-Tudor. Newcastle: Cambridge Scholars Publishing: 57-68.

Năstăsoiu, Dragoş Gheorghe. 2016. “A New Sancta et Fidelis Societas for Saint Sigismund of Burgundy: His Cult and Iconography in Hungary during the Reign of Sigismund of Luxemburg." Hungarian Historical Review 5.3: 587-617.

Neményi, Mária and Judit Takács. 2016. "Main Breadwinner Women in Hungary and their Work-Family Balance Related Coping Strategies." Intersections 2.3: 97-117.

Ní Dhúill, Caitríona. 2016. "Refusing the Child: Weininger, Edelman, Kertész." Poetics Today, 37.3: 369-385. http://ezproxy-prd.bodleian.ox.ac.uk:2066/10.1215/03335372-3599315

Niessen, James P. 2016. "Hungarian Refugees of 1956: From the Border to Austria, Camp Kilmer, and Elsewhere." Hungarian Cultural Studies 9: 122-136. https://doi.org/10.5195/ahea.2016.261

Nurse, Lyudmila et al. 2016. "Media Consumption and Self-Identification: Hungarian and Slovak Case Study." Identities: Global Studies in Culture and Power. 23.6: 705-724.

Pakucs-Willcocks, Mária. 2017. "Between "Faithful Subjects" and "Pernicious Nation": Greek Merchants in the Principality of Transylvania in the Seventeenth Century." Hungarian Historical Review 6.1: 107-136.

Pastor, Peter. 2016. “American Reception and Settlement of Hungarian Refugees in 1956-1957." Hungarian Cultural Studies 9: 197-205. https://doi.org/10.5195/ahea.2016.255

Petö, Andrea. 2016. "Feminism and Neoliberalism: Peculiar Alliances in the Countries of Former 'State Feminism."' Solidarity in Struggle - Feminist Perspectives on Neoliberalism in East-Central Europe. Ed. Eszter Kováts. Budapest: Friedrich-Ebert Stiftung: 108-112.

Petrás, Éva. 2016. "Escape into Emigration: Christian Democratic Social Welfare Politician Bela Kovrig and the Hungarian State Security, 1946-1948." Hungarian Studies Review 43.1-2: 23-38. http://epa.oszk.hu/00000/00010/00051/pdf/EPA00010_hsr_2016_023-038.pdf 
Varga, Zsuzsanna. "Selected English-Language Bibliography of Interest for Hungarian Cultural Studies: 2016-

2017." Hungarian Cultural Studies. e-Journal of the American Hungarian Educators Association, Volume 10 (2017) DOI: $10.5195 /$ ahea.2017.312

Prajda, Katalin. 2017. "Florentines' Trade in the Kingdom of Hungary in the Fourteenth and Fifteenth Centuries: Trade Routes, Networks, and Commodities." Hungarian Historical Review 6.1: 40-62.

Primecz, Henriett et al. 2016. "Information and Communications Technology's Impact on Work-Life Interference: Cases of 'Employee-Friendly Organizations.'” Intersections 2.3: 61-83.

Quigley, Colin. 2016. “Confronting Legacies of Ethnic-National Discourse in Scholarship and Practice: Traditional Music and Dance in Central Transylvania." Journal of Folklore Research 53.3: 137-165.

Rady, Martyn. 2015. Customary Law in Hungary: Courts, Texts, and the "Tripartitum." Oxford: Oxford UP.

Roginer, Oszkar. 2016. "Identity Shift in the Literature of Vojvodina's Hungarian Community, 1992-2010." Hungarian Studies Review 43.1-2: 155-182. http://epa.oszk.hu/00000/00010/00051/pdf/EPA00010_hsr_2016_155-182.pdf

Roters, Katharina. 2014. Hungarian Cubes: Subversive Ornaments in Socialism. Zurich: Park Books.

Rowland, Antony. 2016. “A Dialectic of Forgetting: János Pilinszky and Ted Hughes.” Comparative Literature 68.1: 46-58.

Sári, Zsolt. "Social Traumas, Community Building, Ecological Thinking, Solidarity: The Social Functions of the Hungarian Open Air Museum." Acta Ethnographica Hungarica 61.2: 419-429.

Sárkány, Mihály. 2016. "Hungarian Ethnographers in Non-European Territories — A Revival after 1990." Acta Ethnographica Hungarica 61.1: 13-35.

Scheibner, Tamás. 2015. "Building Empire through Self-Colonization: Literary Canons and Budapest as Sovietized Metropolis." Postcolonial Europe? Essays on Post-Communist Literatures and Cultures. Ed. Dobrota Pucherová and Róbert Gáfrik. Leiden-Boston: Brill Rodopi: 215-241.

Seláf, Levente. 2016. "Saint Martin of Tours, the Honorary Hungarian." Hungarian Historical Review 5.3: 487-508.

Simon, Attila. 2013. The Hungarians of Slovakia in 1938. East European Monographs. New York: Columbia University Press.

Szarvas, Zsuzsa. 2016. "Fragments of Rural Hungarian Jewish Culture." Acta Ethnographica Hungarica 61.2: 395-418.

Széchenyi, Kinga. 2016. Stigmatized: A History of Hungary's Internal Deportations during the Communist Dictatorship. Translation of: Megbélyegzettek. A kitelepítések tragédiája (Pomáz: Kráter, 2008). Trans. Katica Avvakumovits. Saint Helena: Helena History Press.

Strausz, László. 2014. "Producing Prejudice: The Rhetoric of Discourses in and around Current Films on Roma-Hungarian Interethnic Relations." Romani Studies 24.1: 1-24. . 2014. "Back to the Past: Mnemonic Themes in Contemporary Hungarian Cinema." East European Film Bulletin March 15 : n.p. https://eefb.org/essays/back-to-the-past/ . 2011. "Archeology of Flesh: History and Body-Memory in Taxidermia." Jump Cut 53 http://www.ejumpcut.org/archive/jc53.201 
Varga, Zsuzsanna. "Selected English-Language Bibliography of Interest for Hungarian Cultural Studies: 2016-

2017." Hungarian Cultural Studies. e-Journal of the American Hungarian Educators Association, Volume 10 (2017) DOI: $10.5195 /$ ahea.2017.312

. 2009. "The Politics of Style in Miklós Jancsó's The Red and The White and The Lord's Lantern in Budapest." Film Quarterly 62.3: 41-47.

Takács, Róbert. 2016. "In the Pull of the West: Resistance, Concessions and Showing off from the Stalinist Practice in Hungarian Culture after 1956." Hungarian Historical Review 5.4: 814-833.

Teszelsky, Kees. 2016. "The Crown of Hungary before and after the Hungarian Crowning: The Use of the Holy Crown of Hungary in Hungarian Revolts and Habsburg Representation between 1604 and 1611." Hungarian Studies 30.2: 167-173.

Tímár, Andrea. 2016. “The Murder of the Mother Tongue: Agota Kristof's The Notebook. Bicultural Literature and Film in French and English. Eds. Peter I. Barta and Phil Powrie. London: Routledge, 223-236.

Tőke, Lilla. 2016. "The Outsider Within: Béla Tarr and Hungarian National Cinema." Hungarian Cultural Studies 9: 90-100. https://doi.org/10.5195/ahea.2016.259

Török, Zsuzsa. 2016. "Sartorial Heroism and Nation-Building: Female Cross-Dressing in Nineteenth-Century Hungarian Fiction (a Case Study).” Hungarian Studies 30.1: 73-87.

Turán, Tamás and Carsten Wilke, eds. 2016. Modern Jewish Scholarship in Hungary - the "Science of Judaism" Between East and West. Berlin and Boston: De Gruyter Oldenbourg. [Forthcoming Review in this journal, 2018, by David Mandler].

Uhrin, Dorottya. 2016. "The Cult of Saint Katherine of Alexandria in Medieval Upper Hungarian Towns." Hungarian Historical Review 5.3: 557-586.

Unkovski-Korica, Vladimir. 2016. "World War II and the National Question: The Origins of the Autonomous Status of Vojvodina in Yugoslavia." Europe-Asia Studies 68.10: 17121735.

Valuch, Tibor. 2016. "Following the Life Stories of Participants in the 1956 Hungarian Revolution.” Hungarian Cultural Studies 9: 165-183. https://doi.org/10.5195/ahea.2016.253

VanDenmark, Christopher M. 2016. "Empress Elisabeth ('Sisi') of Austria and Patriotic Fashionism."Hungarian Cultural Studies 9: 1-10. https://doi.org/10.5195/ahea.2016.254

Varsa, Eszter. 2017. “'The (Final) Solution of the Gypsy-Question:' Continuities in Discourses About Roma in Hungary, 1940s-1950s.” Nationalities Papers 45.1: 114-130.

Varga, Bálint. 2016. The Monumental Nation: Magyar Nationalism and Symbolic Politics in Fin-de-Siècle Hungary. New York: Berghahn.

Varga, Zoltán Z. 2016. "Seeking Facts and Witnesses in a Post-Factual Age: The Year in Hungary." Biography: An Interdisciplinary Quarterly 39.4: 621-628.

Varga, Zsuzsanna, ed. 2017. Antal Szerb, Reflections in the Library. Oxford: Legenda.

Vasvári, Louise O. 2016. "The Yellow Star and Everyday Life under Exceptional Circumstances: Diaries of 1944-1945 Budapest." Hungarian Cultural Studies 9: 43-59. https://doi.org/10.5195/ahea.2016.260

Vincze, László and Jessica Gasiorek. 2016. “The Moderating Effect of Valenced Contact: Slovak Language Media Use, Acculturation and L2 Confidence Among Young Hungarian Speakers." Journal of Multilingual \& Multicultural Development 37.8: 805-816. 
Varga, Zsuzsanna. "Selected English-Language Bibliography of Interest for Hungarian Cultural Studies: 2016-

2017." Hungarian Cultural Studies. e-Journal of the American Hungarian Educators Association, Volume 10 (2017) DOI: $10.5195 /$ ahea.2017.312

Virginás, Andrea. 2016. Cultural Studies Approaches in the Study of Eastern European Cinema Spaces, Bodies, Memories. Newcastle: Cambridge Scholars Press. [Reviewed in this issue by Lilla Tőke].

Viskolcz, Noémi. 2016. “The Fate of Johannes Sambucus’ Library. “ Hungarian Studies 30.2: 155-166.

Watson, Alexander. 2016. "Managing an 'Army of Peoples': Identity, Command and Performance in the Habsburg Officer Corps, 1914-1918." Contemporary European History 25.2: 233-251.

Wilson, Tracie L. 2017. "Migration, Empire, and Liminality: Sex Trade in the Borderlands of Europe." Aspasia 11.1: 71-96.

Zaller, Robert. 2016. “A Hungarian Classic, Beautifully Translated: Antal Szerb's Traveler and the Moonlight." Hungarian Studies 30.2: 259-262.

Zsadányi, Edit. 2015. "Voicing the Subaltern by Narrating the Communist Past through the Focalization of a Child in Gábor Németh's 'Are You a Jew?' and Endre Kukorelly's 'The Fairy Valley.' Postcolonial Europe? Essays on Post-Communist Literatures and Cultures. Eds. Dobrota Pucherová and Róbert Gáfrik. Leiden-Boston: Brill Rodopi: 175-193.

Zsadányi, Edit. 2015. Gendered Narrative Subjectivity - Some Hungarian and American Women Writers. Berlin, New York: Peter Lang. [Reviewed in this issue by Agatha Schwartz]. Zombory-Moldován, Béla. 2014. The Burning of the World: A Memoir of 1914. Trans. Peter Zombory-Moldovan. New York: NYRB Classics. [Reviewed in the 2016 issue by Judit Kádár]. https://doi.org/10.5195/ahea.2016.235

Zupka, Dušan, 2016. Ritual and Symbolic Communication in Medieval Hungary under the Árpád Dynasty (1000 - 1301). Amsterdam: Brill. 